\title{
CLINICO-EPIDEMIOLOGICAL STUDY OF GENITAL ULCER DISEASE AT A TERTIARY CARE CENTRE IN AN URBAN SETTING IN INDIA.
}

Meetesh Agrawal, Y. S. Marfatiya

1. Associate Professor. Department of Dermatology, Gardi Medical College, Ujjain.

2. Professor \& Head. Department of Dermatology, Govt. Medical College, Vadodara.

\section{CORRESPONDING AUTHOR}

Dr. Meetesh Agrawal,

Department of Dermatology,

R.D. Gardi Medical College, Ujjain,

E-mail: drmeetesh@yahoo.co.in

Ph: 00919827317412

ABSTRACT: BACKGROUND: In developing countries, the proportion with STDs who present with genital ulcers is high compared to developed nations. AIM: To study clinic-epidemiological profile of cases presenting with genital ulcer disease at a tertiary care centre. STUDY SETTINGS: Present study was carried out in Department of skin and VD, Medical College and SSG Hospital Baroda between June 2001 and Feb. 2003. MATERIAL AND METHODS: A cross sectional study was conducted. Sexually active male or female having genital ulcer with history of exposure in patient or partner. Total 216 cases were included in the study. Detailed history was taken and was recorded. Inquiries were made regarding age, educational status, occupation, marital status and details of their complaints. History of sexual activity was elaborately taken. All the details pertaining to number of exposures, last exposure, sexual partners, sexual orientations and condom use were noted. RESULTS: Most of the case are males i.e.91.5\%. 56\% cases were married. It includes 53.7\% males and more than $88 \%$ females. This implies that the high extramarital transmission occurs in wives and they bear the consequences of extramarital activity of their husbands. . 63.8\% of unmarried male cases and $51.9 \%$ of married male cases had sexual exposure to sex workers. Along with genital ulcer, the most common associated findings were lymph node enlargement (72..4\%) and subprepucial discharge (13..6\%) in males. In females, $(35.3 \%)$ cases had vaginal discharge. the commonest ulcerative STD was herpes progenitalis $(52.8 \%)$ followed by syphilis (30.5\%). CONCLUSION: The present study highlights that the high risk sexual behavior was present in cases, irrespective of the marital and educational status. Female attendance was very low which may be due to asymptomatic STIs, social financial reason and their dependence on male partners for seeking treatment.

KEY WORDS: Genital ulcer disease

INTRODUCTION: "Venereal disease is the most formidable enemy of the human race: an enemy entrenched behind the strongest human passions and deepest social prejudice"

\section{Sir William Osler}

Genital ulcer syndrome is a frequent presentation of sexually transmitted disease, especially in developing countries, like ours. There are number of different causes of genitor ulcer disease, and since the clinical presentation of each may be variable and the treatment for each different, genital ulcer syndrome creates considerable and management problem for clinicians. 
In developing countries, the proportion with STDs who present with genital ulcers is high compared to developed nations. Herpes progenitalis is the most common cause of genital ulcer in developed and most parts of developing world.

The genital ulcer disease or genital ulcer syndrome is defined as a breach of the epithelium of the genital skin or mucous membranes, usually by sexually acquired organisms resulting in the formation of lesions.

During the course of the disease the inguinal and/or femoral lymph nodes may be enlarged resulting in a combination of ulceration and lymphadenopathy for be appropriate.

Ulcerative, erosive, pustular or vesicular genital lesion(s), with or without regional lymphadenopathy, caused by a number of sexually transmitted infections (STIs) and non-STIrelated conditions. For most young, sexually active patients with genital ulcer disease (GUD), etiology is related to an STI. Most often it is due to herpes simplex virus type 1 or 2 (HSV-1 or HSV-2), causing genital herpes. ${ }^{1}$ More than one etiology may be found if a careful evaluation is conducted. ${ }^{2}$ Other STI causes of GUD are Treponema pallidum spp., causing primary syphilis, Haemophilus ducreyi, causing chancroid. - Chlamydia trachomatis serotype L1, 2 or 3, causing lymphogranuloma venereum (LGV). - Klebsiella granulomatis, causing granuloma inguinale (donovanosis). Non-STI-related infections or conditions causing GUD may also be seen (see Differential Diagnosis, below). Even after a complete diagnostic evaluation, at least $25 \%$ of patients with GUD have no laboratory-confirmed diagnosis. ${ }^{3}$ The cause of GUD can be related to a number of factors, such as geographical area where sexual intercourse has taken place; socioeconomic factors; gender of sexual partners; number of partners; HIV status and local prevalence; drug use; commercial sex; and circumcision. ${ }^{4}$ GUD constitutes at most $5 \%$ of visits to physicians for a possible STI. ${ }^{5}$ About 70 to $80 \%$ of genital ulcers are due to HSV-1 or HSV-2. Genital ulcers in sexually active persons can be associated with two or more pathogens. Women ${ }^{6}$ and men with GUD are at increased risk of acquiring and transmitting HIV.

\section{Risk factors}

- The following are risk factors for STI-related GUD ${ }^{7}$ :

- Sexual contact with:

o MSM.

o A person with GUD.

o A new partner.

o A partner who is from or has travelled to an endemic area.

o Sex workers and their clients.

o An anonymous sexual contact (e.g., from the Internet, bathhouse, rave/circuit party).

o A person who is infected with HIV.

- Travel to endemic areas.

- Living in region(s) in Canada experiencing outbreaks (e.g., syphilis).

- Previous genital lesions or STI.

- Drug use in self and/or partner.

\section{AIM \& OBJECTIVES OF STUDY:}

1. To study epidemiological profile of cases presenting with genital ulcer disease.

2. To study clinical presentation of cases with ulcer disease. 


\section{MATERIAL AND METHODS:}

Present study was carried out in Department of skin and VD, Medical College and SSG Hospital Baroda between June 2001 and Feb. 2003. Two hundred and sixteen cases having genital ulcers were included in the study. The present study is a cross sectional study. The study was conducted after taking approval from the ethical committee of the institute.

INCLUSION CRITERIA: Sexually active male or female having genital ulcer with history of exposure in patient or partner.

EXCLUSION CRITERIA: The patients not giving consent were excluded from the study.

Detailed history was taken and was recorded. Inquiries were made regarding age, educational status, occupation, marital status and details of their complaints.

History of sexual activity was elaborately taken. All the details pertaining to number of exposures, last exposure, sexual partners, sexual orientations and condom use were noted. History of taking any treatment for the present ailment was noted. Past history of genital ulcer or any other STD and its treatment was taken.

All the cases were asked about the similar or other STD in their partners. Patients were asked about smoking, alcohol consumption and other drug addictions. History of traveling was noted.

All the patients were thoroughly examined and relevant positive and negative finding were noted. External genitalia, perianal region, skin and oral mucosa were inspected. Genital ulcers, inguinal and other lymph nodes were palpated.

All the cases were subjected to VDRL, ELISA for HIV and HbsAg tests. Those cases having urethral discharge were subjected to gram smear for Gonococci. Those having vaginal discharge were examined for Trichomoniasis, Candidiasis, and bacterial vaginosis. Cases were treated as per the syndromic approach for treatment of genital ulcer. The cases having syphilis with HIV seropositivity were treated like Neurosyphilis, as none of the patients consented for CSF examination. Thirty two cases, selected at random were given azithromycin $100 \mathrm{mg}$ on first day, Followed by $500 \mathrm{mg}$ orally once a day for 10 day.

Those patients who were having inadequate response to treatment at the end of 2 wks were treated with acyclovir $200 \mathrm{mg}$ orally, times a day for 7-10 days.

All the patients were given health education, counseling and were encouraged regarding partner notification, condom use and abstinence from sexual activity till the subsidence of symptoms. All patients were separately counseled by male and female counselor (as per the case) also and were taught about the use of condoms on demand.

RESULTS AND DISCUSSIONS: The study of 216 cases of Genital ulcer disease was carried out in the Department of skin and VD, medical college and S.S.G. Hospital, Vadodara. The findings of the study were analyzed and compared with other studies.

In the present study, the youngest and oldest patients were 15 and 60 years old respectively. Majority of the cases were from 15-25 years age group. V. Grover et al . Have also reported the 15-25 years age group as the commonest age to have STD's.

High incidence of STD in young adults is found as they are sexually more active. The incidence decreases with increase in age as the sexual activity decreases.

In the present study female attendance was only $7.9 \%$. Other studies also showed low female attendance ay STD clinics. Though STDs are fairly equal in males and females but number of females coming to STD clinics is low. This may be due to: 
1. More changes of asymptomatic infections in females.

2. Females may not be in apposition to utilize the available due to family, social and financial. Also, they may to be dependent on their male partners for seeking treatment.

3. Many of the female cases might be taking treatment from private doctors who may be allopathic, homeopathic or ayurvedic. They may also go to gynecologists and gynecology OPD of public hospitals.

Thus, most of the female suffering from STD are not getting proper treatment and are prone to complications. Also they act as carriers and may easily contract HIV as their mucosal barrier is compromised due to presence of STD.

More than half of the cases in present study as well as other studies had low level education. These case are likely to have limited or no knowledge regarding STDs and safe sex.

As high as $16 \%$ case having higher secondary level education or above, and are likely to have knowledge about STDs were having GUD. This reflects the behavioral aspect of STD problem.

$56 \%$ cases were married. It includes $53.7 \%$ males and more than $88 \%$ females. This implies that the high extramarital transmission occurs in wives and they bear the consequences of extramarital activity of their husbands.

More than half of the cases were married. This signifies that the multipart activity and casual sex on goes on irrespective of the marital status. Further, the risk of transmission of disease is not restricted to their spouses but also to future generation as well, through vertical transmission.

More than half of the cases in present study had sexual exposure to sex workers. $63.8 \%$ of unmarried male cases and $51.9 \%$ of married male cases had sexual exposure to sex workers. $30 \%$ of the unmarried cases had exposure to a friend and may of them were indulging in multi partner activity.

Out of 17 female, cases 15 were married and all had infection from their husbands.

V. Grover et al. have reported that $50 \%$ of their cases had sexual relation to sex workers while Nitin S. Vora has reported $73.9 \%$ case having such exposure to sex workers. This is consistent with the present study where more than half cases had sexual exposure to sex workers.

Thus, sex workers remain transmitters as for as STI transmission is concerned of course the clients as abridge population carry the infection to their spouses.

Along with genital ulcer, the most common associated findings were lymph node enlargement $(72 . .4 \%)$ and subprepucial discharge $(13 . .6 \%)$ inmales. In females, $(35.3 \%)$ cases had vaginal discharge. On internal examination sings of cervicitis may be detected in these cases. This signifies the importance of internal examination in females.

On the basis of clinical diagnosis, the commonest ulcerative STD was herpes progenitalis $(52.8 \%)$ followed by syphilis (30.5\%). J.parmar et al. and S. Khandpur et al. have also reported herpes and syphilis as the commonest causes of GUD.

Herpes progenitalis is the most common genital ulcer as reported by various European studies.90 Being a recurrent condition and having potential of asymptomatic viral shedding, herpes has lot of epidemiological significance. Concomitant herpes and HIV has a lot of impact on clinical presentation, course of disease and relapse rate.

CONCULUSION: The present study highlights that the high risk sexual behavior was present in cases, irrespective of the marital and educational status. Female attendance was very low which 
may be due to asymptomatic STIs, social financial reason and their dependence on male partners for seeking treatment. Most of the female cases were married and all of them had acquired infection from their spouses. Around $1 / 3^{\text {rd }}$ cases were from rural areas and most of them do not avail facility of treatment from qualified doctors. Following the simple flowcharts of syndromes approach, the health workers can treat such patient during early of their disease.

More than half the cases had past history of STDs suggesting continuation of high risk sexual behavior. Further, around $1 / 3^{\text {rd }}$ cases were alcoholic and they not take appropriate precautions including use of condoms for STIs prevention.

Herpes progenitalis was the most common observed GUD followed by syphilis and chancroid. Clinico serologic correlation was present in only $56 \%$ cases and hence there was some over treatment in remaining cases. However, 13 cases diagnosed as non-syphilis were VDRL positive. Thus, mixed venereal diseases are more frequent than expected and all these cases can be covered using syndromic management.

\section{REFERENCES:}

1. Mertz KJ, Trees D, Levine WC, et al. Etiology of genital ulcers and prevalence of human immunodeficiency virus infection in 10 US cities. The Genital Ulcer Disease Surveillance Group. J Infect Dis 1998;178:1795-1798.

2. DiCarlo RP, Martin DH. The clinical diagnosis of genital ulcer disease in men. Clin Infect Dis 1997;25:292-298.

3. Centers for Disease Control and Prevention. Sexually transmitted disease guidelines 2002. MMWR Morb Mortal Wkly Rep 2002;51(RR-6):11-25.

4. Ballard R. Genital ulcer adenopathy syndrome. In: Holmes KK, Sparling PF, Mardh PA, et al, eds. Sexually Transmitted Diseases. Toronto, ON: McGraw Hill; 1999: 887-892.

5. Piot P, Meheus A. Genital ulcerations. In: Taylor-Robinson D, ed. Clinical Problems in Sexually Transmitted Diseases. Boston, MA: Martinus Nyhoff; 1985: 207.

6. Celum CL. The interaction between herpes simplex virus and human immunodeficiency virus. Herpes 2004;11(suppl 1):36A-45A.

7. Agence de développement de réseaux locaux de services de santé et de services sociaux. Direction de santé publique. Campagne provinciale de prévention de la syphilis "Je suis Phil". 1. La syphilis, état de situation et caractéristiques. Quebec, QC: Direction de santé publique; 2004.

8. Vijay Grover et al. Sexually Transmitted Diseases awareness and sexual behavior- A study in clinical setting in an Urban area of Delhi: Indian Sex Trans Sid 1999:20 No.1,1620.

9. Mohan C Shendre, Rajnarayan R Tiwari. Social Risk Factore for sexually transmitted diseases. Indian j Dermatol Venereol Leprol 2992:68:25-27.

10. Vijay Grover et al. Sexually Transmitted Diseases awareness and sexual behavior- A study in clinical setting in an Urban area of Delhi: Indian Sex Trans Sid 1999:20 No.1, 1620.

11. Sujay Khandpur et al. Clinico - epidemiological profile and HIV seropositivity of STD patients. Indian J Dermatol Venereol Leprol, 2001:67:62-65.

12. Juotin Parmar et al. Clinical Profile of STDs at civil Hospital, Ahemdabad: Indian J Sex Trans Dis. 2001:22 No.1:14-16. 
Table 1 Age wise Distribution of cases

\begin{tabular}{|c|c|c|c|}
\hline \multirow[t]{2}{*}{ Gender } & \multirow{2}{*}{$\begin{array}{l}\text { Present study } \\
\text { (GUD) }\end{array}$} & \multicolumn{2}{|c|}{ Comparative Studies (STD) } \\
\hline & & $\begin{array}{l}\text { V.grover } \\
\text { et al. } 8\end{array}$ & $\begin{array}{l}\text { M.C. Shendre } \\
\text { et al. }{ }^{9}\end{array}$ \\
\hline $0-14$ & $00(0.0 \%)$ & $1.2 \%$ & $0.6 \%$ \\
\hline $15-25$ & $90(41.7 \%)$ & $42.0 \%$ & $38.5 \%$ \\
\hline $26-35$ & $74(34.3 \%)$ & $39.0 \%$ & $41.9 \%$ \\
\hline $36-45$ & $44(20.4 \%)$ & $14.2 \%$ & $18.9 \%$ \\
\hline$>45$ & $08(03.7 \%)$ & $3.6 \%$ & - \\
\hline Total & $213(100 \%)$ & & \\
\hline
\end{tabular}

Table 2 Sex wise Distribution of Cases

\begin{tabular}{|l|l|l|l|}
\hline \multirow{2}{*}{$\begin{array}{l}\text { Age } \\
\text { (in years) }\end{array}$} & \multirow{2}{*}{$\begin{array}{l}\text { Present study } \\
\text { (GUD) }\end{array}$} & \multicolumn{2}{|c|}{ Comparative Studies (STD) } \\
\cline { 3 - 4 } & & $\begin{array}{l}\text { V.grover } \\
\text { et al. 10 }\end{array}$ & $\begin{array}{l}\text { S.Khandpur } \\
\text { et al. 11 }\end{array}$ \\
\hline Male & $199(92.1 \%)$ & $79.8 \%$ & $72.63 .6 \%$ \\
\hline Female & $17(7.9 \%)$ & $20.2 \%$ & $26.0 \%$ \\
\hline Total & $216(100 \%)$ & & \\
\hline
\end{tabular}

Table 3 Marital Status of Cases

\begin{tabular}{|l|l|l|l|}
\hline Marital Status & Male & Female & Total \\
\hline Married & $106(53.7 \%)$ & $15(88.2 \%)$ & $121(56.0 \%)$ \\
\hline Unmarried & $69(34.7 \%)$ & $00(0.0 \%)$ & $69(31.9 \%)$ \\
\hline Widowed & $07(3.5 \%)$ & $02(11.8 \%)$ & $09(4.2 \%)$ \\
\hline Divorced & $06(3.0 \%)$ & $00(0.0 \%)$ & $06(2.8 \%)$ \\
\hline Separated & $08(4.0 \%)$ & $00(0.0 \%)$ & $08(3.7 \%)$ \\
\hline Staying away & $03(1.5 \%)$ & $00(0.0 \%)$ & $03(1.4 \%)$ \\
\hline Total & $199(100 \%)$ & $17(100 \%)$ & $216(100 \%)$ \\
\hline
\end{tabular}


Table 4 Sexual Partners of Cases

\begin{tabular}{|c|c|c|c|c|c|c|c|}
\hline \multirow[t]{2}{*}{ Sexual Partners } & \multicolumn{2}{|c|}{ Married } & \multicolumn{2}{|c|}{ Unmarried } & \multicolumn{2}{|l|}{ Other } & \multirow{2}{*}{ Total } \\
\hline & Male & Female & Male & Female & Male & Female & \\
\hline Sex workers & $\begin{array}{c}55 \\
(51.9 \%)\end{array}$ & $\begin{array}{c}0 \\
(0 \%)\end{array}$ & $\begin{array}{c}44 \\
(63.8 \%)\end{array}$ & $\begin{array}{c}0 \\
(0 \%)\end{array}$ & $\begin{array}{c}14 \\
(58.3 \%)\end{array}$ & $\begin{array}{c}0 \\
(0 \%)\end{array}$ & $\begin{array}{c}113 \\
(52.3 \%)\end{array}$ \\
\hline $\begin{array}{l}\text { Girl } \\
\text { Friend/Friend }\end{array}$ & $\begin{array}{c}15 \\
(14.2 \%)\end{array}$ & $\begin{array}{c}0 \\
(0 \%)\end{array}$ & $\begin{array}{c}21 \\
(30.4 \%)\end{array}$ & $\begin{array}{c}0 \\
(0 \%)\end{array}$ & $\begin{array}{c}5 \\
(20.8 \%)\end{array}$ & $\begin{array}{c}0 \\
(0 \%)\end{array}$ & $\begin{array}{c}43 \\
(19.9 \%)\end{array}$ \\
\hline Unknown & $\begin{array}{c}05 \\
(4.7 \%)\end{array}$ & $\begin{array}{c}0 \\
(0 \%)\end{array}$ & $\begin{array}{c}02 \\
(2.9 \%)\end{array}$ & $\begin{array}{c}0 \\
(0 \%)\end{array}$ & $\begin{array}{c}01 \\
(4.2 \%)\end{array}$ & $\begin{array}{c}0 \\
(0 \%)\end{array}$ & $\begin{array}{c}08 \\
(3.7 \%)\end{array}$ \\
\hline No exposure & $\begin{array}{c}31 \\
(29.2 \%)\end{array}$ & $\begin{array}{c}15 \\
(100 \%)\end{array}$ & $\begin{array}{c}02 \\
(2.9 \%)\end{array}$ & $\begin{array}{c}0 \\
(0 \%)\end{array}$ & $\begin{array}{c}04 \\
(16.7 \%)\end{array}$ & $\begin{array}{c}0 \\
(0 \%)\end{array}$ & $\begin{array}{c}52 \\
(24.1 \%)\end{array}$ \\
\hline & $\begin{array}{c}106 \\
(49.0)\end{array}$ & $\begin{array}{c}15 \\
(6.9 \%)\end{array}$ & $\begin{array}{c}69 \\
(31.9 \%)\end{array}$ & $\begin{array}{c}0 \\
(0 \%)\end{array}$ & $\begin{array}{c}24 \\
(11.1 \%)\end{array}$ & $\begin{array}{c}2 \\
(1.0 \%)\end{array}$ & \\
\hline Total & $\begin{array}{r}12 \\
(55\end{array}$ & $9 \%)$ & 6 & $.9 \%)$ & $\begin{array}{r}2 \\
(12\end{array}$ & $1 \%)$ & $\begin{array}{c}216 \\
(100 \%)\end{array}$ \\
\hline
\end{tabular}

Table 5 Examination findings of cases:

\begin{tabular}{|c|c|c|c|}
\hline Finding & $\begin{array}{l}\text { Male } \\
(n=199)\end{array}$ & $\begin{array}{l}\text { Female } \\
(n=17)\end{array}$ & $\begin{array}{l}\text { Total } \\
(n=216)\end{array}$ \\
\hline Genital ulcer & $199(100 \%)$ & $17(100 \%)$ & $216(100 \%)$ \\
\hline $\begin{array}{l}\text { Discharge } \\
\text { Urethral } \\
\text { Sub prepucial } \\
\text { Vaginal }\end{array}$ & $\begin{array}{l}6(3.0 \%) \\
27(13.6 \%) \\
\quad-\end{array}$ & $\begin{array}{c}- \\
- \\
6(35.3 \%)\end{array}$ & $\begin{array}{l}6(2 . .8 \%) \\
27(12.5 \%) \\
6(2 . .8 \%) .\end{array}$ \\
\hline Phimosis / paraphimosis & $7(3.5 \%)$ & - & $7(3.2 \%)$ \\
\hline Genital Warts & $0(0 \%)$ & $0(0 \%)$ & $0(0 \%)$ \\
\hline $\begin{array}{l}\text { Lymph nodes } \\
\text { Enlarged } \\
\text { Bubo }\end{array}$ & $\begin{array}{l}144(72.4 \%) \\
14(7.0 \%)\end{array}$ & $\begin{array}{l}11(64.7 \%) \\
0(0 \%)\end{array}$ & $\begin{array}{l}155(71.8 \%) \\
14(0.5 \%)\end{array}$ \\
\hline Perianal & $8(4.0 \%)$ & $2(11.8 \%)$ & $10(4.6 \%)$ \\
\hline Skin & $16(8.0 \%)$ & $4(23.5 \%)$ & $20(9.3 \%)$ \\
\hline Other mucosa & $3(1.5 \%)$ & $1(5 . .9 \%)$ & $4(1.9 \%)$ \\
\hline
\end{tabular}


Table 6 Clinical Diagnosis of cases:

\begin{tabular}{|c|c|c|c|}
\hline \multirow{2}{*}{$\begin{array}{l}\text { Clinical Diagnosis } \\
\text { Genital ulcer }\end{array}$} & \multirow{2}{*}{$\begin{array}{ll}\text { Present } & \text { study } \\
\text { (GUD) } & \\
\text { 199(100\%) } & \end{array}$} & \multicolumn{2}{|c|}{ Comparative Studies (STD) } \\
\hline & & $\begin{array}{r}\text { J parmar etal. } 12 \\
\text { (Ahemdabad) }\end{array}$ & $\begin{array}{l}\text { S Khadpur etal. } 11 \\
\text { (AIIMS, New Delhi) }\end{array}$ \\
\hline Herpes progenitalis & $114(52.5 \%)$ & $38.9 \%$ & $30.0 \%$ \\
\hline Syphilis & $66(30.5 \%)$ & $40.3 \%$ & $39.6 \%$ \\
\hline Chancroid & $24(11.1 \%)$ & $13.3 \%$ & $28.0 \%$ \\
\hline GI & $03(1.4 \%)$ & $1.3 \%$ & $1.2 \%$ \\
\hline LGV & $00(0.0 \%)$ & $0.0 \%$ & $1.2 \%$ \\
\hline Mixed & $09(5.2 \%)$ & $5 . .9 \%)$ & N.A. \\
\hline Total & $216(100 \%)$ & & \\
\hline
\end{tabular}

